\section{UNIVERSITY}

of DEBRECEN

FACULTY OF

HeALTH

NYÍREGYHÁZA

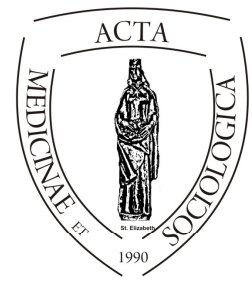

ACTA

MedSOC

VOLUME 8.

2017

\title{
Intervention and competences of social workers in the process of regulating parental rights and obligations concerning a minor child
}

\author{
Katarína Chovancová
}

Catholic University in Ružomberok, Faculty of Theology in Košice

\begin{abstract}
The goal of this paper is to examine the social worker's options of intervention in the process of regulating parental rights and obligations concerning a minor in Slovakia. Because this research is in its early stages, the aim of this paper is to provide the general description of this process of social and legal protection of minors in Hungary. The first part of this paper describes the theoretical background of the process. The second part examines the methodology of the research used in this paper. The paper then subsequently provides the aforementioned description based on the interviews of the social workers at Centre for Child Welfare and Family and also employees of the district office from the Custody Department. The society considers the work of a social worker an easy one, however, such practice requires certain skills and qualifications which are not only personal, but also professional. For this very reason the second part highlights the relevance of the social worker's competences, which are an inseparable part of every worker. The preliminary results of the research of the competences of the social workers in the RPRO process from both countries are presented via narrative method.
\end{abstract}

Keywords: Competences. Intervention. Research. Social and legal protection of child. Social work.

DOI: $10.19055 /$ ams.2017.8/24/6 


\section{Introduction}

The principle of subsidiarity is one of social work principles. The focus of this principle is to always evaluate any kind of problem at its smallest level. We only advance to higher level when the resources of the lowest level prove to be insufficient (Matoušek, 2003). Thus, we can conclude that this principle considers the society to be constructed from the bottom to the top, mainly in natural order (an individual, family, town, region, country, international society). The abovementioned hierarchy suggests that this principle is aimed at the need to help and support (Uhál', 2006).

Family is the most important part of any society and therefore it must be protected. Social workers specialized in the field of social and legal protection of children often encounter various kinds of family problems. Parents' divorce is usually the origin of these problems and it frequently causes family crises. The fact that long-lasting family problems are the main cause of dysfunctional families must also be mentioned.Today we can see that there are families which don't give the essential features of the development of children living in it could jeopardise much. (Bodonyi, Busi, Hegedűs, Magyar, Vizely, 2006)

\section{Theoretical basis}

\section{Intervention}

Several types of social support are available especially for those families that are unable to help themselves. When family is unable to fulfil its role in society, other social units are obliged to help this social institution called family (Š́ulová, 2014). Pope Leo XIII. in his Rerum Novarum claims that if a family finds itself in exceeding distress without any prospect of extricating itself, it is right that extreme necessity be met by public aid, since each family is a part of the commonwealth (RN 11). In accordance with the Act No. 305/2005 of Social Protection of Children and Social Guardianship (hereinafter referred to as SPOCHaSG), every citizen is obliged to notify the authorities of any abuse of children rights. This obligation concerns not only legal but also natural persons. The authorities of SPOCHaSG can be notified in written form, telephonically, in person or via email. Similary in Act No. 1997 XXXI, ofthe protection of children and guardianship administration by $\S 17$, the institutions and person must give an indicationof child endagermet to Centre for Child Welfare and Family. To regulate the parental rights and obligations (hereinafter referred to as the RPRO process), the social worker has to follow these steps: 
- registration

- analysis

- $\quad$ establishment of a social plan aimed at a child

- intervention - implementing changes concerning social situation

- conclusion (Levická, 2002)

The divorce is considered to be a large societal issue. Its reasons and consequences prove to be even larger. The priority of the social worker's in this area (in Slovakia called Guardian Ad Litem) or in Hungary a Family Assistant, Case Supervisorand Office worker is the protection of child's best interests and elimination of the consequences of the divorce on the child. Direct work with client is important with both the parents and the children. The fact that the family cannot exists together as a unit has a large impact on the child, but the behaviour of the parents after the divorce has more serious consequences. Parents in most cases do not want to find an effective solution to a problem because of the feelings of injustice from the side of their ex spouse. In these specific cases the direct intervention of the social worker is needed. The strengthening and developing of parenting skills, becomes for development in problem situations (Mihályné, Bárány, Szombathelyiné, 2015). As part of the professional training in Slovakia (2014) mandated by university, an opportunity presented itself to observe the work of a social worker, mainly while recording a case in legal proceedings. At the same time a few shortcomings in the intervention process were spotted.

\section{Competences of social workers}

The term "competence" is derived from Latin word competentia, which can be translated as authority, domain, qualification or the ability to perform certain action. Other synonyms are frequently used instead of the word competence, such us expertise, efficiency, capacity, required quality and others. Veteška and Turecki define competence as the capability to perform a particular activity. However, Mertens defines competence as a combination of knowledge and skills that enable an individual to work in various domains and, mainly, it allows him to handle the changes in his carrier.

Based on these definitions we can say that semantic meaning of the term competence is far from being homogenous.

By combining all mentioned meanings, we can also conclude that to be competent means to possess certain powers for particular scope of activity in particular domain. It also means to act responsibly with an expert knowledge in a particular domain.

However, it has to be noted that the possession of such competence doesn't necessarily guarantee successful outcome of specific situations. D.McClealland in hisTesting for competence rather than for inteligence (1973) claims that 
"Critical thinking and decision making are not the only things that make a good social worker. "The most important part is to be able to take advantage of one's competences. However, the profession of social worker is often considered to be simple by general public (Chovancová, 2015). Still, marriage crises are very intense and they are one of the most common social problems, since couples usually enter into marriage based on reciprocal feelings. The social worker have to accept a client personality.It is very important that the problems staff dealt together with the client and respect his dignity. The client has the right to choose from the various alternative solutions, except where the child may be at risk. (Szili - Darók, 2008) It is true that some cases ensuring child's rights and obligations might seem simplistic, but in reality relations between parents are often heavily undermined and the intervention of social workers is frequently required, sometimes lasting several years. Above-mentioned cases of intervention are presented in the Picture 1. and Table 1.

\begin{tabular}{|l|c|c|c|c|c|c|c|}
\hline & \multicolumn{2}{|l}{ YEAR } \\
\cline { 2 - 8 } & $\mathbf{2 0 0 8}$ & $\mathbf{2 0 0 9}$ & $\mathbf{2 0 1 0}$ & $\mathbf{2 0 1 1}$ & $\mathbf{2 0 1 2}$ & $\mathbf{2 0 1 3}$ & $\mathbf{2 0 1 4}$ \\
\hline Number of cases & 71 & 73 & 74 & 81 & 80 & 52 & 35 \\
& 837 & 829 & 759 & 629 & 782 & 622 & 415 \\
\hline Number of & 109 & 108 & 108 & 124 & 120 & 93 & 96 \\
investigations & 267 & 718 & 436 & 326 & 849 & 538 & 206 \\
\hline $\begin{array}{l}\text { Number of investiga- } \\
\text { tions per one case }\end{array}$ & $\mathbf{1 , 5 2}$ & $\mathbf{1 , 4 7}$ & $\mathbf{1 , 4 5}$ & $\mathbf{1 , 5 2}$ & $\mathbf{1 , 4 9}$ & $\mathbf{1 , 7 7}$ & $\mathbf{2 , 7 1}$ \\
\hline
\end{tabular}

Table 1: Field social work in natural environment of the client.

The results are compiled by the author of this research based on the statistics $\mathrm{V}$ (MPSVR SR) 12-01 (provided by The Ministry of Labour, Social Affairs and Family of the Slovak Republic).

Throughout the years 2008-2012, the number of investigations per one case has drastically changed. The increase in investigations per one case is obvious even in 2013, but this number is even greater in 2014. From 2012 to 2014 this number has increased by up to $46,23 \%$. Even though the number of investigated families has decreased, the workload of social workers has significantly increased. 


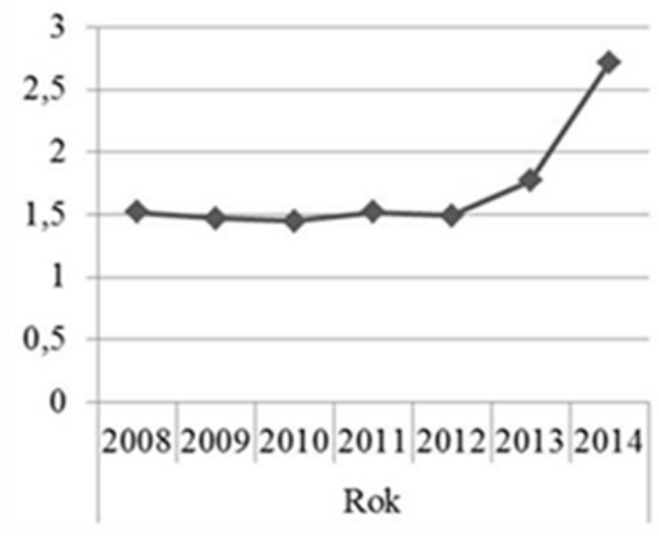

Picture 1. Number of investigations per one case.

\section{Methodology}

The qualitative research was chosen to achieve the goal of this article. This type of research focuses especially on the understanding of the particular situation while the researcher is expected to reflect primarily his own opinions and propose his own solutions (Šedová, 2007). This qualitative research investigates each individual case, presents different links and facts. Acquired experience in this particular doma2in also makes a contribution. This methodology allows us to acquire detailed description and the insight into the issues of social work.

\section{Methodology of qualitative research}

Data for this dissertation are acquired by means of semi-structured in-depth interviews thanks to their flexibility. The interview allows us to understand an opinion of other and the answers are recorded in suitable form. It was already mentioned in the theoretical part of this research that the social worker has to follow specific steps and methods during the intervention. That's why the structure of research questions was drawn up for the purposes of this research. However, various authorities of social and legal protection of children function differently in foreign countries and foreign social workers cooperate differently with their clients. That's why it was necessary to adapt the questions for the purposes of our research. Similar approach was employed in the case of social competences. The process called open coding was used to analyse the data of the research and the results are presented using the "show cards" method. 
Based on the answers of the interviewees from individual countries, the aim of the research is to elaborately analyse the intervention process. Open code method and the "show cards" method have been used to analyse data and subsequently present results of this dissertation.

Because the research has not yet been finished, this article instead presents the general description of workings behind the social and legal protection of children in the RPRO process in Hungary. The outcome of social worker's competence research is presented via narrative method.

\section{Aim}

The main aim of the dissertation is to come up with any possibilities to improve the work and the competences of social workers of SPOCHaSG in the RPRO process in the Slovak republic.

Secondary aims were also defined to ensure the main aim is accomplished:

1. To find out the methods used in the RPRO process in the following countries: Hungary and Poland.

2. To find out how social workers put their specific competences to use.

\section{Collecting data}

The semi-structured interview was realized during one month internship in Hungary from 15th February to 15th March at Debrecen Reformed Theological University in 2016. Employees of Centre for Child Welfare and Familyas well as employees of the district office from the Custody Department participated in the interviews.

\section{The research sample}

Currently, the research sample consists of 4 social workers from Centre for Child Welfareand Family and of 4 office workers from the Custody Department.

\section{Research questions}

\section{Primary research question}

What are the methods used by social workers and which competences use in the RPRO process?

\section{Specific research question 1.}

Social evidence: How do you usually start cooperation with your client?

\section{Sample interview questions:}

What methods do you use in your cooperation with a client?

What all ranked within the administration to work with the client in the process of RPRO to a minor child at this stage? 


\section{Specific research question 2.}

Analysis/diagnostic: How you obtain relevant information from the client?

Sample interview questions:

What is the investigation in the natural surroudings of the client?

What will be assessed, monitored in the investigation within the RPRO to a minor child?

\section{Specific research question 3.}

Establishment of a social plan aimed at a child: How progress the planning with family in the RPRO to a minor child?

\section{Sample interview questions:}

How you do the planning in relation to your client, if is with you?

How does the planning within the internal and external networking?

\section{Specific research question 4.}

Intervention- implementing changes concerning social situation:

\section{Sample interview question:}

What can you propose within the RPRO?

In what way are you trying to actively engage clients on solving their own problem?

\section{Specific research questions 5.}

Conclusion: How and when is the end of cooperation with the family?

\section{Sample interview questions:}

What services are you use to further provide?

Which competences do social workersuseand how do they take advantage of them?

\section{Specific research questions 6.}

Which competencies are most used in the process in RPRO to a minor child?

\section{Sample interview questions:}

What skills should a social worker employ to perform required competences?

From your point of view, which method proves to be the most efficient?

What part of your knowledge do you use most frequently to perform such competence?

\section{Another questions}

What is your opinion on mediation? Are you using the mediation as a training method or are you prefer a working with a mediator? 
What is your opinion on supervision? Have you on opportunity to participate on supervision? Have you more kinds of supervision in your institution? Which kind of supervision do you prefer?

\section{Results}

The answers to the individual questions aimed at intervention and competence are presented below. Due to the fact that the size of the article is limited by the number of pages, the process of intervention is presented via descriptive method. Description of both the intervention and competences are analysed on the basis of observation and on the basis of the answers of the participants.

\section{Social worker's intervention in the RPRO process in Hungary}

The Centre for Child Welfare and Family (hereinafter referred to as Centre) is the place where a family having problems should seek help. The Centre's predominant role is to aid children and their parents in crisis situations with methods of social work and to provide psychological counselling, mediation and other services right in the Centre. After assessing the social situation of their clients, the social workers are obliged to draw up a 6 months long social plan aimed at helping a child. Besides the interviews, an opportunity presented itself to witness the work of family assistant both in the Centre and natural environment of the client (household of the family).

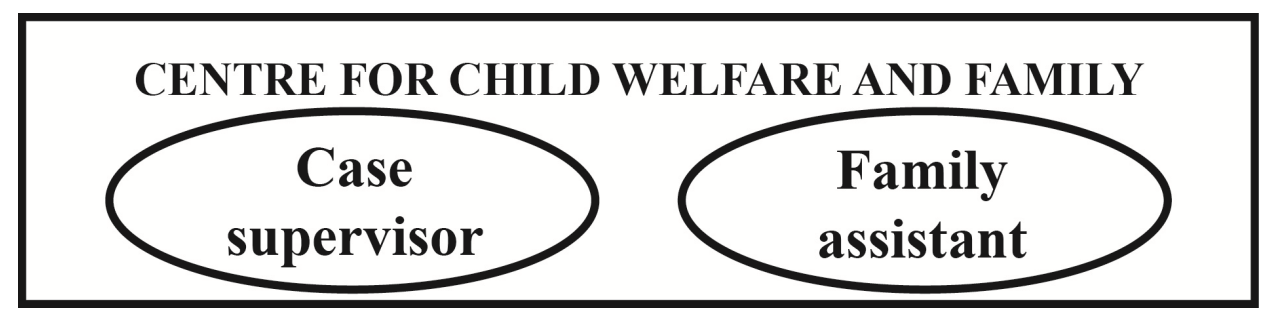

Picture 2. Centre for Child welfare and family.

As can be seen from the Picture 2. the principal figures in the Centre are case managers and family assistants. The family assistant is highlighted in the picture, because he is the first person to make contact with a family. They investigate the household of the family and other institutions if need be (school, medical centre ...). They are the first person to make contact with parents and a child. Family assistant helps a family in their natural environment and multiple times in the 
Centre, where special rooms for such purpose are available. Inquiring about child's opinion on their parent warrants the consent from parents. Should the family assistant's intervention prove insufficient to aid the family in the period of 6 months (e.g. the disputes between the parents continue after the RPRO process and the child is still endangered) the parents are forced to sign a cooperation agreement. By signing the agreement, the parents agree to use all possible services provided by family assistants to eliminate the problem. This case requires drawing up a new social plan, this time for one year. The family assistants are also obliged to inform the Custody Department in the district office about such case. The department is bound to find solution to the family issue with legal methods such as fines for violating the assigned custody arrangement or not paying the alimony. The department can also issue supervised contact with a child and rarely prohibit the contact with one parent entirely. The Custody Department is represented by an officer, while the family assistant still maintains contact with the family.

It was already mentioned that the employee of the Custody Department is an office worker who is obliged to start a hearing no later than 8 days after he was notified of the breach of the child rights. This hearing ${ }^{1}$ takes place in the department. The worker is obliged to contact all persons involved in the case, such as parents, children and a family assistant who was assigned to the family. Various types of evidence are being examined during this hearing; the family assistant introduces encountered problems, lists services used by a family and presents their personal experience with this family. Both parents and a child are interrogated during this hearing.

In some cases the relationships between former spouses are undermined to such an extent that they ignore the decisions issued by the authorities and they neglect their parental rights and obligations. In such case, the Custody Department is entitled to further regulate rights and obligations regarding a minor ${ }^{2}$.

As can be seen from the Picture 3., a family cooperates not only with family assistants, but also with case supervisors. The supervisors help those families

\footnotetext{
${ }^{1}$ According to the respondents, the hearing concerning one particular case may take place multiple times, especially in cases of lengthy inquiry. However, the office worker is obliged to issue a decision to amend or revoke the parental rights and obligations no later than 60 days after the commencement of the hearing.

${ }^{2}$ It has to be noted that the Custody Department can begin the RPRO process only two years after the court mandated divorce and child custody.
} 
that are currently in the hearing at the Custody Department. ${ }^{3}$ For example, one of the parents may be allowed to only meet a child under the supervision of an expert. In such case, this parent may only meet his child during specific hours at the Centre of the Child Welfare and Family, accompanied by the case supervisor. During the visit, the case supervisor uses the social work methods to monitor the situation and ask for child's opinion.

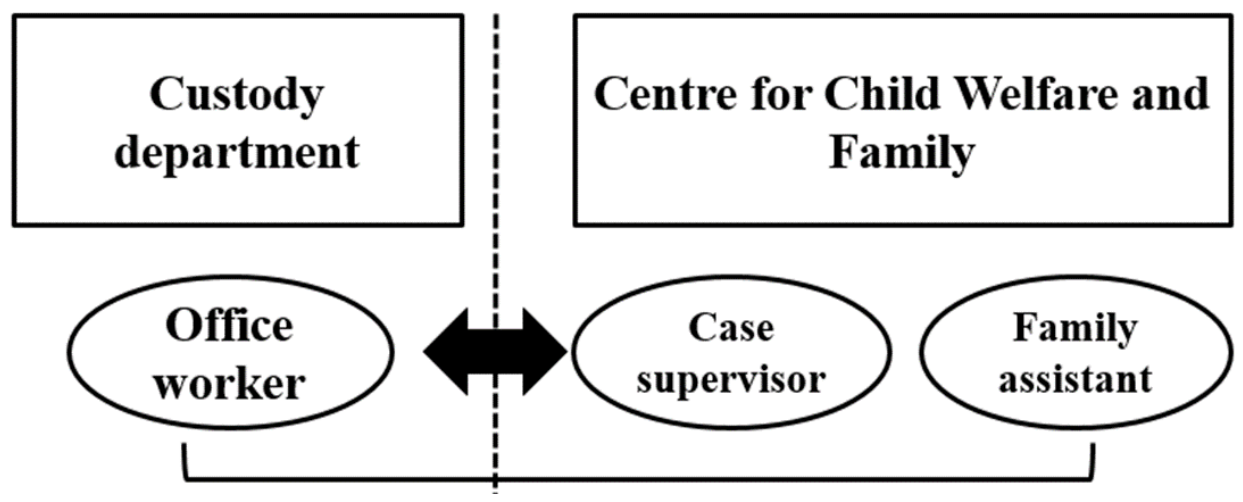

Picture 3. Cooperation with family assistant and case supervisors.

\section{Various competences of social workers in the RPRO process}

\section{a) Always put the welfare of a child first}

The interviewees usually claimed that the most important part of this competence is to know how to adjust the communication to child's age, especially when a social worker tries to find out child's opinion. Older children are usually asked straight about their opinion, for they are able to perceive the reality rationally. However, younger children need more time and support. Respondents also emphasized the ability to understand child's non-verbal communication. Sensitive approach is also closely related to the profession of a social worker, because younger children usually cannot rationally understand the divorce of their parents, but they experience it rather emotionally. All the Slovak interviewees also mentioned that to find out the child's opinion, you have to create a feeling of safety. A Child should not feel like being in court.

The interviewees working in the Centre also mentioned the implementation of games into the process, especially for younger children. They claimed that

\footnotetext{
${ }^{3}$ The employees of the Centre for Child Welfare and Family were divided into family assistants and case supervisors on 1.1.2016
} 
playing games is the most efficient way to find out a relevant answer without putting pressure on a child. During her internship, the author of the research also witnessed the communication between a social worker and a child by means of a game, not only in natural environment of a child but also in the Centre's room specially designed for communication with children. Experienced interviewees also stated that the communication by means of a game is the most efficient way to find out child's opinion, but even under these conditions some children do not wish to share their feelings. In such a case, it is very important to be able to spot and identify signs showing that certain facts and memories are unpleasant to the child. A social worker need to be aware of such signs, because it is the child's way of expressing that something is wrong. However, Matoušek claims that a social worker should not try to determine cause of a problem too early. Sometimes the cause of the problem might seem clear, but a social worker should never be hasty in making conclusions (Matoušek 2008). Majority of social workers agrees that avoiding certain topic is a bad sign, but the child must be given time to build the trust towards a social worker. In these cases, building of trust proved to be the most significant competence. This process may sometimes take few months. Some of interviewees also mentioned the competence to respect child's boundaries. As was already mentioned, three kinds of people can obtain child's opinion in Hungary: case supervisors, family assistants and office workers from the Custody Department. The interviewees from this department claim that their competences include mainly decision making. Still, they try to use their communicative methods to help a child and they often remind both parents that even though they are no longer spouses, they still have parental responsibilities. Interviewees also state that a social worker should not be biased and must be impartial to be able to assess the situation. One of the interviewees also mentioned empathy, but right after he added that a social worker should not be too emotional, especially when trying to find out child's opinion. This competence is really difficult to master, because some children are emotionally unstable, which could influence a worker.

\section{b) The competence to cooperate with a client, colleagues and non-clients}

- with clients

It is imperative not to underestimate the client and his problems. At some point, the social worker might deem the problems easily resolvable, but the client is unable to find an adequate solution by himself due to certain circumstances, e.g. bad mental state. Some of the interviewees highlighted the personal contact with the client, so that the client feels a genuine concern for his wellbeing. Other interviewees mention efficient communication. It is imperative to prepare the plan of social work with the family toward the capabilities and abilities of the 
client and to explain what is expected of the client and most importantly to define boundaries.

- with colleagues and non-clients

The interviewees stated that mutual trust between the colleagues in very important, especially in the case of endangered child. Centre workers conduct the investigations in pairs. They prefer direct personal contact when negotiating time and date of meeting. When cooperating with non-clients, telephone contact is greatly appreciated. Some interviewees stated that case conferences are very beneficial in assessing adequate decision of a case. The conferences serve to have a situation evaluated by other involved experts. The interviewees acknowledged that the case conferences markedly alleviate their work with the clients.

\section{c) The competence to guide the client to independence}

To guide both parents to independence, social workers need to be able to estimate mental preparedness of the clients to hold responsibility for the emerged situation. However, the interviewees noted that a long-term cooperation with a psychologist or a psychiatrist is usually required. However, the mind-set of the former spouses proves to hinder this process, because they act solely on their own accord and have no interest to do anything else. As the interviewees claimed, the most efficient method to guide a person is commendation. A good example would be leaving a parent with their child alone after some time during the supervised contact to express trust. This method allows the social workers to elevate and reinforce the positive attributes of a parent. Expressing trust towards a client was also mentioned as important competence- social workers express their interest to aid a parent and their child.

According to some interviewees, gaining the client's trust is also the way to improvement. The parent starts to re-evaluate their situation and tries to improve the status quo, for example by learning how to adequately communicate with their former spouse etc. However interviewees also noted that this change is in most cases impossible.

Another efficient way is to withdraw from the conflict between spouses by retreating to the background and enabling the spouses to solve the problem on their own. A social worker must be readily available to intervene in case of failure. The workers also report positive experience concerning the cooperation with other institutions such as the police, schools and medical centres. Such institution immediately report when a child is in danger. The positive fact remains that the same person who was assigned to the family in the first place is the one to resolve their problems if they are still unable to solve them on their own after intervention. This proves to be a great advantage for that social worker, because they have prior knowledge of the family's situation and are able to effectively continue their work. 


\section{d) The competence to contribute to the organization}

This competence encompasses the ability to follow the laws and regulations of the organization, to set one's own competences, to handle one's own work and to grasp the general knowledge of a worker's institution. Some interviewees emphasised the following of the ethical codex of social worker.

\section{e) The competence to make a decision}

The term objectivity was often mentioned by the employees of the Custody Department. Some have pointed out that a social worker needs to be objective, not to mention sensitive, and emotionally intelligent. They also need to have control of their emotions. According to the opinion of one of the employees, a person with no sensitivity should not be working in this domain at all. Simultaneously, it is important to maintain emotional distance from the client. As the interviewees stated that it requires a great deal of patience to follow all the possible working proceduresand verifyall the evidence and other related information. All these duties help to correctly assess the situation and only then make correct decision.

\section{f) Ability to effectively communicate with an adult client}

All the interviewees mentioned that the key to this competence was to firstly try to talk to parents and give them some advice. The parents must be explained why some facts are important. The workers try to make them understand what kind of impact their behaviour and their acts can have on their children. Even though parents may consider their behaviour to be positive, it may have negative impact on their child. The advice is typical first step, but it usually proves to be unsuccessful. Each individual personality must be considered, because in some cases the opinion of a worker is not sufficient enough and whole situation must be explained in detail. This type of conversation requires the mastery of theoretical knowledge in the field of social work.

Parents usually blame each other during such conversations. In such cases, a worker is obliged to step in and warn the parents that they are obliged to respect each other. Anger, blame and hatred are frequently part of this process and a worker should communicate within boundaries, which means that they must refuse to be provoked by clients and cannot let sympathy overwhelm them. A worker also needs to communicate at client's level. He should not give advice to a client who is mentally devastated. A worker's competence to be empathic is also very significant for the process of getting close to him. (Table 2.) 


\begin{tabular}{|c|c|c|}
\hline \multicolumn{2}{|c|}{ COMPETENCIES } & SKILLS \\
\hline \multicolumn{2}{|c|}{$\begin{array}{l}\text { Always put the welfare of a } \\
\text { child first }\end{array}$} & $\begin{array}{l}\text { know how to adjust the communication to child's age, } \\
\text { understand child's non-verbal communication, sensitive } \\
\text { approach, create a feeling of safety, implementation of } \\
\text { games, the communication by means of a game, spot and } \\
\text { identify signs, building of trust, respect child's bounda- } \\
\text { ries, should not be biased, empathy }\end{array}$ \\
\hline \multirow{2}{*}{$\begin{array}{l}\text { The compe- } \\
\text { tence } \\
\text { to cooperate }\end{array}$} & with a klient & $\begin{array}{l}\text { not to underestimate the client, the personal contact with } \\
\text { the client, efficient communication, imperative to pre- } \\
\text { pare the plan of social work, explain what is expected }\end{array}$ \\
\hline & $\begin{array}{l}\text { With colle- } \\
\text { gaus and } \\
\text { non-klients }\end{array}$ & mutual trust, direct personal contact, conferences \\
\hline \multicolumn{2}{|c|}{$\begin{array}{l}\text { The competence to guide } \\
\text { the client to independence }\end{array}$} & $\begin{array}{l}\text { estimate mental preparedness, commendation, elevate } \\
\text { and reinforce, trust towards a client, gaining the client's } \\
\text { trust, withdraw from the conflict }\end{array}$ \\
\hline \multicolumn{2}{|c|}{$\begin{array}{l}\text { The competence to con- } \\
\text { tribute to the organization }\end{array}$} & $\begin{array}{l}\text { the ability to follow the laws and regulations of the or- } \\
\text { ganization, handle one's own work and to grasp the } \\
\text { general knowledge of a worker's institution, following of } \\
\text { the ethical codex of social worker }\end{array}$ \\
\hline \multicolumn{2}{|c|}{$\begin{array}{l}\text { The competence to make a } \\
\text { decision }\end{array}$} & $\begin{array}{l}\text { objectivity, emotionally intelligent, maintain emotional } \\
\text { distance, working procedures }\end{array}$ \\
\hline \multicolumn{2}{|c|}{$\begin{array}{l}\text { Ability to effectively com- } \\
\text { municate with an adult } \\
\text { client }\end{array}$} & $\begin{array}{l}\text { explaining, make them understand, personality must be } \\
\text { considered, the mastery of theoretical knowledge, warn, } \\
\text { respect each other, communicate within boundaries, } \\
\text { communicate at client's level, empathic }\end{array}$ \\
\hline
\end{tabular}

Table 2. Summary off skills in competencies.

\section{Suggestions, evaluation and conclusion}

In Slovakia the social worker called Guardian Ad Litem is the person who usually establishes the first contact with a family. The worker represents the Central Office of Labour, Social Affairs and Family in Slovakia (hereinafter reffered to as UPSVaR), the departement of SPOCHaSG). This worker is assigned to a family by court order after the start of proceedings.

The role of Guardian Ad Litem is mainly to represent a child in legal proceedings, to examine the situation in the family, ascertain the opinions of the child and, during the whole process, fulfilling the needs for safety and assurance associated with building emotional bonds of the child toward both parents.

As was mentioned before, several shortcomings were spotted during the professional training and the interviewing of the social workers. These shortcom- 
ings considerably influence the intervention process of the social worker. The lack of direct work with the client due to the administrative workload together with too many cases assigned to a single social worker proved to be the most important issues. As opposed to Hungary, where in the RPRO process three people from two institutions can be involved, in Slovakia only one Guardian Ad Litem is involved in this process. From examining the description of RPRO process in Hungary, we can propose the implementation of new position of "family assistant" in the RPRO process in Slovakia for the sake of improvement of the process. This implementation of family assistant would spell several other benefits for the Guardian Ad Litem in specific steps of the process, but mainly in their joint cooperation. A detailed analysis of the benefits and possibilities of this position will be presented after the research has concluded. In my opinion, the implementation of this position would markedly improve the development of the social and legal protection of minors in Slovakia.

\section{Competences - conclusion}

A social worker is the one to manage his own active participation in a case. The participant's answers suggest that it is very important for workers to mirror their own actions, emotions, and reasoning while working on a family case, because it helps them stay on top of things. A social worker is considered qualified only when he can achieve set objectives effectively and appropriately. This includes good knowledge of appropriate tools, such as social work methods and procedures. However, the social work as helping profession can be effective only when each individual social worker has met both qualification and personality requirements. Together, these two make for professional competences.

In the current state of our research, Hungarian participants have provided much more detailed information considering social worker's competences than Slovak participants. It is also reflected in the abovementioned fact. The only such profession in the Slovak system of social and legal protection of children is that of a guardian ad litem, which results in less effective cooperation with families. A guardian ad litem cannot fully devote himself to the family, what is then reflected in his practical skills. There are three such specialised professions in Hungarian system, which offers much more possibilities for workers to deal with families effectively. 


\section{References}

1. Bodonyi Edit, Busi Etelka, Hegedűs Judit, Magyar Erszébet, Vizely Ágnes (2006): Család, gyerek, társadalom. Budapest, Bölcsész Konzorcium.

2. Chovancová Katarína. (2015): Kompetencie sociálnych pracovníkov ako súčast' profesionalizácie odboru. In: Lýdia Lešková, Zasvätení a poslaní pre sociálne služby a odkaz bl. Sáry Salkaházi. Prešov, Vydavatel'stvo Michal Vasko. 159-167.

3. Korintus Mihályné, Kovácsné Bárány Ildikó, Szombathelyiné dr. Nyitrai Ágnes (2015): Napközbeli gyermek ellátás. In: Rácz Andrea, A gyermekvédelem megújulási alternatívái, Budapest, Rubeus egyesület elnöke. http://rubeus.hu/wp-content/uploads/2015/08/gyermek_es_ifjusagvedelmi _tanulmanyok_otodik_kotet.pdf

4. LEV XIII. (2008): Rerum Novarum. In : Dokumenty sociálnej náuky cirkvi. Trnava, Vydavatel'stvo SSV.

5. Levická Jana (2002): Metódy sociálnej práce. Bratislava, Vydavatel'stvo VEV.

6. Matoušek Oldřich (2003): Slovník sociální práce. Praha, Vydavatel'stvo Portál.

7. Szili-Darók Ildikó (2008): Szociális problémamegoldás a szociális munka eszközeivel. Budapest, Kiadja a Nemzeti Szakképzési és Felnőttképzési Intézet

8. Šed'ová Klára a kol. (2014): Kvalitativní výzkum v pedagogických vědách. Praha, Vydavatel'stvo Portál.

9. Šul'ová Michaela (2014):Program ProFamily - sanačný program pre rodiny. Ružomberok, Vydavatel'stvo Verbum.

10. Uhál' Martin (2006): Sociálna náuka cirkvi v základných princípoch. Košice, Vydavatel'stvo TypoPress.

11. Zákon 305/2005 Z.z. o sociálnoprávnej ochrane detí a o sociálnej kuratele a o zmene a doplnení niektorých zákonov.

12. 1997. évi XXXI. törvény a gyermekek védelméről és a gyámügyi igazgatásról.

\section{Katarína Chovancová}

A Kassai Katolikus Egyetem Teológiai Karán (Košice of Catholic University of Theological Faculty) végzett szociális munkásként. Jelenleg ugyanezen Kar PhD hallgatója. Kutatásának középpontjában a gyerekek és a fiatalok védelme áll. Munkája során sporton keresztül is foglalkozik veszélyeztetett gyerekekkel, mely ezen célcsoport számára kiváló személyiségfejlesztésre is lehetőséget ad. 